УДК: 7.045

ББК: 85.155

A43

DOI: $10.18688 /$ aal $188-1-16$

Roger Ferrer Ventosa

\title{
The Encryption Code: The Symbolic Language of Alchemy Engraving Books ${ }^{1}$
}

My area of interest as an art historian concentrates on symbolic language. I am studying how human beings can represent metaphysical ideas in a visual way, a goal that is a notorious oxymoron because "metaphysical", by definition, refers to something imperceptible by the senses, therefore non-visual. Alchemy engraving books are especially interesting for this objective because of their use of a codified visual language; with this symbolic language, they share knowledge using visual skills. Their artists communicated ideas that only experts in the subject could grasp; moreover, with this ciphered symbolic language, they provided themselves a protection during years of public persecutions.

From this use of metaphorical code, I am especially interested in alchemy engraving books. At the conference I will talk about that remarkable visual universe, particularly their visual expression in the engraving books from the $16^{\text {th }}$ to the $18^{\text {th }}$ centuries, probably the golden age of this codified and symbolic language.

The first alchemist illuminated manuscripts were published in the $14^{\text {th }}$ century $[7, \mathrm{p} .105]$. Since then, artists and adepts translated into images in their emblematic books the knowledge fruit of their research in the athanor, the alchemical oven, in a slow process of lexical and grammatical creation of their symbols and language. During the $15^{\text {th }}$ century we can notice a change in the paradigm inside this area, from a study linked to the science - science in that moment to a different sight, more related to spiritual analogies and symbolical sacred image syntaxes.

Therefore, perhaps the most outstanding matter since those years is the extraordinary proliferation of treats and books with engravings and emblems. From the art historian criterion, we can observe the high point of alchemy then, when the lab experiments and the spiritual reflection came together in engraving techniques, in books of extremely visual nature. We can talk about a logo-iconic form, based on words as well as on images.

The practice was named the hermetic science after Hermes, the protector and legendary the first practitioner. In addition to this terminology, the practice has used others, like "Sacred Art", "Divine Art", or "Great Work", while "alchemy" was popularized during the Middle Ages. How can we define these practices? They are blurred by the mystery consubstantial to them. In fact, researchers do not know everything about them, they (we) move forward with help from allusions, deciphering with effort the alchemy symbolic language. More than theoretical framework

1 This article has been carried out thanks to the support of the FPU Grant Programme from the Spanish Ministry of Education, Culture and Sport of Spain, and thanks to the support of the Project HAR2014-55271-P from the Spanish Ministry of Economy and Competiveness too. 
based on logic, it consists of an investigation that involves a spiritual sublimation of the investigation.

I referred to alchemy as science on purpose, in order to avoid its habitual valuation from Illustration onwards underestimated as pseudo-science. Alchemists needed many skills in different areas of knowledge. In an emblem of one of the most remarkable alchemy books, Khunrath's Amphitheatrum sapientiae aeternae (1595) we see the three levels of knowledge that an alchemist should know in order to be wise. The levels are spiritual dimension - on the left, in the oratory - , art and technical skills - on the table - , and scientific aspect - on the right, with the ovens -; consequently, a good alchemist needed to be an expert in praying, playing music, and doing research in

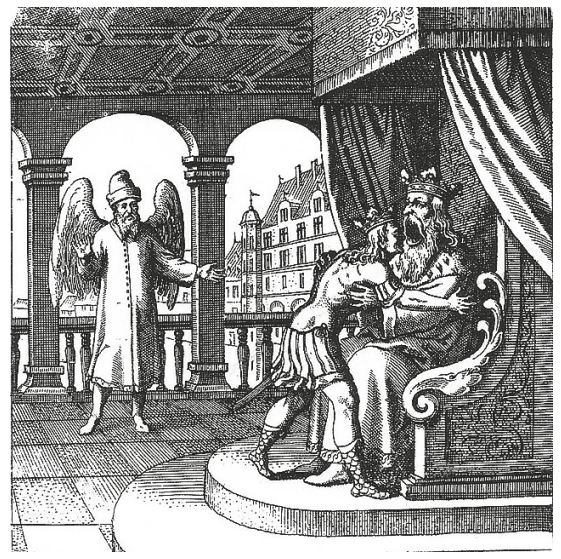

Fig. 1. Lambsprinck. De lapide philosophico, 1677. Foundation of the Works of C. G. Jung, Zürich. http://dx.doi.org/10.3931/e-rara-39181 chemistry (Ill. 24).

Alchemy was a science; at least it was considered as such by several researchers of that period. As Wouter Hanegraaff pointed out: "the realities of alchemy as a historical phenomenon differ dramatically from the picture of alchemy that still dominates the popular imagination" [8, p.63]. There is a common misunderstanding in general public: they make the mistake of equalizing the practice with the creation of gold, whatever that may mean. The widespread literalism, in its cultural peak, avoids searching for a direct meaning, if not a previous and barbaric version of the aristocratic chemistry, but this is a senseless attitude; in fact, alchemy is one of the deepest and most symbolic codes created in the history of culture (Fig. 1).

We should avoid studying alchemy at the letter level, because the Hermes science shared its knowledge through figures and parables. For instance, if we analyze this engraving from a literal reading, we could claim that this image, from Lambsprinck's De lapide philosophico, is an apology to cannibalism. According to this conclusion, in a version of Medea's myth, the king father eats the head of his son, the prince - both of them wear a crown; - a figure with wings observes the scene, hence he could testify about the crime, unless he decides to fly away.

Even in the scientific field some scholars regard alchemy as a rudimentary stage of chemistry, a stance that was recently refuted by some historians of science, above all Newman and Principe. The alchemy inquiry has value in itself [6, pp.11-15]. During the last decades some art historians have argued a different point of view and have increased their interest and esteem towards alchemy, not only for esotericism and related areas, but also for the history of science's own ranks [13, pp. 386, 341, n. 4].

In Alchemy Tried in the Fire these two professors of history of science studied the common space shared by chemistry and alchemy; chymistry was the word coined by Newman and Principe to explain this fact. The Great Work implied much laboratory research; in those centuries, not only did alchemy consist of a spiritual reflection, but also of a hard research in chemistry field [12, p. 35]. It is however unnecessary to emphasize that we analyse it from a non-dual starting point: science and spiritual matters are not opposites, as we are going to see at the end 
of the presentation. Alchemy's starting point joins spirit and matter in a vitalist principle ${ }^{2}$. The science of Hermes tries to spiritualize the matter and materialize the spirit.

Even some of the best chemists would be the best alchemists as well. For instance, there was the case of Eiraneus Philalethes, according to Newman and Principe the pseudonym of one of the greatest chemists of the $17^{\text {th }}$ century. There was also George Starkey: "darkly veiled in the allegorical writings of Eiraneus Philalethes but lucidly expressed in operational terms in the private 1651 letter of George Starkey - the real author of the Philalethes tracts - to his friend Robert Boyle" [13, pp. 406-407].

What are the main elements of the Hermes science? Most of the alchemists used the sulphur-mercury theory, derived from the conception about metals and minerals by Aristotle. According to his idea, "minerals and metals are the product of the exhalation of an 'earthy smoke' and a 'watery vapour' from inside the earth. When they became imprisoned within the earth and combined, they formed various metals and minerals according to the different proportions of smoke and vapor" [4, p. 214]. These vapours were transformed into sulphur and mercury. To this scheme, Sendovigious and other paracelsians added salt, which balanced the other two [4, p.215].

However, what is the reason that explains this tendency to veil the alchemy ideas? The scholar will find at least four reasons. The first one was to be cautious; that attitude would avoid the consequences of a gold fever. The tragedy of Edward Kelley could be paradigmatic in this sense: Rudolf II, the Holy Roman Emperor in the court of Prague, imprisoned Edward Kelley, a partner of John Dee in his operations that had a trickster reputation. Rudolf II, truly fascinated by alchemy, wanted Kelley to explain to him how he could manage to produce gold. Kelley probably died because of the injuries produced when he tried to escape from the prison.

Another main motive for being careful about the secrets was the kind of methodology preferred in these alchemic circles, an epistemological reason thereupon: alchemists preferred to share knowledge in an indirect way, using a language made by images, symbols and metaphors ${ }^{3}$. Symbols have enciphered information hidden in the great play of the world [6, p. 262]. Symbolic images are on the surface in place of another thing or idea that shows itself in that indirect way. That conforms a simultaneous game of revealing and hiding. This game of opposite directions is the quintessence of art. Symbols come together to activate imagination and to generate feelings [11, p. 25]. This tendency of alchemists led them to create an enciphered system and methodology: wisdom is in the process of grasping the ideas and beauty remains in the veil.

The third reason was perhaps based on the elitist spirit, guided by the biblical verse: "do not throw your pearls to pigs" (Mt. 7:6), the paradigm about knowledge that is different from the one nowadays. In this kind of texts it is better not to speak too clearly, in order to avoid stupid people to know the science as well as the wise [5, p.99]. Disguising information might discourage curious and uninvited eyes [16, p. 127].

Finally, to grasp the fourth principal reason, we must remember the main lines of the political situation in Europe those days, with the most brutal persecutions against heterodox re-

2 Some scholars argue that alchemy propose that vital principle, even hylozoism, with the matter animated, but Newman and Principe denied that [13, pp. 412-415].

3 Pseudo-Dionysious claimed something related to this point: wise people studying this kind of divine or sacred subjects share their knowledge by symbols weird at first sight. In this way: Pseudo-Dionysious, Celestial hierarchy, II, 5 [14, pp. 129-130]. 
ligious beliefs. Symbolic language kept alchemists away from religious problems. Those were days of religious biases and persecutions. If someone wanted to communicate a Christian view that was more or less different from the norm - or a Christian view that could be read as more or less different, - the intellectual had to be cautious. If he did not, he would die like Miguel Servet or Giordano Bruno. In those days of religious wars and persecutions of Lutherans against Anglicans, Anglicans against Catholics, Catholics against Calvinists, and everyone against each other, Hermetics, alchemists, and followers of prisca theologia had to be extremely careful. If someone cannot grasp your ideas, it is less likely that you quarrel with them.

We can remember the many tricks used during the Renaissance and Baroque to get around persecutions. For example, the famous stunt of first publishing the work criticizing the text that will be published later, excusing it as a mistake of youth, following the example of Cornelius Agrippa, a theorist of magic, with his De occulta philosophia, the most remarkable book on this subject in the $16^{\text {th }}$ century. The Dream of Poliphilus, a chant to paganism, presented another option: publishing anonymously.

Mystery is the main way in which the numinous can be grasped by human beings, due to our mind being incapable of understanding the core mysteries of existence and reality. In his idea of the Theatre of Memory, the Renaissance author Giulio Camillo claims directly that a wise person must not speak publicly of the mysteries of God; the wise must speak by riddles [2, p.47]. A sacred hieroglyphic was estimated as a better way, although several of them derived in the intellectual game or simple humorous occurrence.

Finally, we are going to think about the study case: how the visual material in alchemy engraving books works by using for that purpose the example of the representation of non-dualism in that framework. At the beginning of this text, we talked about the ideas represented in a visual way in alchemy engraving books. One of the main concepts in this field is non-dualism. According to some philosophers and anthropologists, Raimon Panikkar for instance, the history of ideas and the mind can be divided into three phases: the initial monism, in which all that exists comes from one point; each person is a microcosm that includes the entire universe and the entire universe is connected with each person.

The second phase is dualism, which separates reality into pairs of opposites in fight. In this way of thinking, reality is divided into two principles with the same power, and for this reason the real is harmed; dualism inflicts a wound on existence. The non-dualist worldview tries to solve the problems generated by dual mentality. Non-dualism claims that those two principles are, in fact, connected. That mind-set intends to join the two principles in a relation again. Without darkness, light would not exist. It has enormous implications in several areas of life, from theology - the nature of God and humans - to philosophy - is there really a division between subject and object? - or even ecology — without the division between human beings and nature, the ecological problems would be different.

Turning for a moment to non-dualism in the history of culture, we find that non-dualism has more weight in Eastern cultures than in Western cultures, with Taoism in China - the world's most famous non-dual symbol: the yin-yang, - the Advaita school and Indian ones such as Tibetan Tantras, Lamaism, and so on. In Western culture, a scholar would find a few examples that stand out, such as Plotinus and other Neo-Platonists, Pseudo-Dionysus and other Christian mystic thinkers, Nicholas of Cusa, Spinoza, or in some ideas presented by post-struc- 


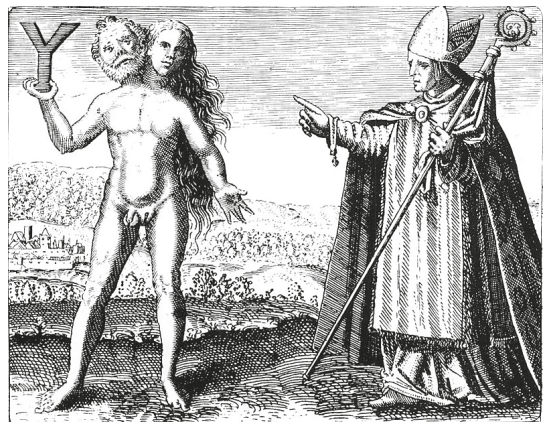

Fig. 2. Michael Maier. Symbola aureae mensae, 1617. Foundation of the Works of C. G. Jung, Zürich. http://dx.doi.org/10.3931/e-rara-7376 tural philosophers such as Foucault, Deleuze or Lévinas - with the theory of the otherness.

Nevertheless, one of the few non-dual currents in Western background is alchemy. This framework is represented with several iconographic motifs. We have chosen the most important ones: an androgyne with two heads and two genital organs, as it is characterized in Michael Maier's Symbola Aureae Mensae (1617), the Y human, two branches joined by the same trunk (Fig. 2).

The androgyne is presented in several graphic ways in alchemy engraving books, but this is probably the most remarkable one among them, with its spectacular shape, worthy of a Hollywood movie ${ }^{4}$. This figure can be represented in the form of the androgyne or in the form of a hermaphrodite, with some differences between them. That human being with two natures is presented in the origins of life, but also in its last stage. The hermaphrodite etymologically is the descendant of Hermes and Aphrodite, that is to say, the son of gnosis - knowledge of the sacred things. They are also the descendant of love, someone who joins love and knowledge in themselves. Love is the core of the Cosmos, the key of all operations.

In certain occasions, the hermaphrodite is engraved together with the sun and the moon, as in one of the engravings from Hermaphroditisches Sonn- und Monds-Kind (1752) ${ }^{5}$. It represents that the human being has achieved the perfect nature. The great artist William Blake was probably guided by this motif for one of his emblem-like creations, Book of Job, in which God the perfection by definition - is represented as someone who joins the sun and the moon, or Apollo and Selene, in the central stripe of the illustration (Ill. 25).

We can find another example of a non-dual iconographic motif in alchemical engravings in the figure of the sacred wedding: a couple, usually represented with crowns, shown embraced and making love. Ancient Greeks named it hieros gamos. The sacred male and female marriage creates the Philosopher's Stone - or the hermaphrodite, in its symbolic language. The sacred wedding is a symbol of the union of the two cosmic principles, woman and man, dry and wet, active and passive, sulphur and mercury in alchemy's framework... Rosarium Philosopharum, one of the most influential books of alchemy, with several different editions, includes this amazing motif (Ill. 26).

In alchemy's cultural horizon we can find more examples of the non-dual way of thinking, although these two are perhaps the most important ones.

In general terms, those emblems and engravings anticipate the surrealism to come [10, pp.216-256; 9, pp.259-261; 3, pp.47-48], with its sense of unusual, shocking, unexpected. And they were also interested in their style of covering up sense, the veils required because of the hermetic mystery that protects the secret, Signum harpocraticum. The remarkable work

4 Later artists used it, like the surrealist Max Ernst in his book inspired by emblems A Week of Kindness (1934). An image quotes the alchemy motif. Available at: https://www.wikiart.org/en/max-ernst/illustration-to-a-week-of-kindness-1934-20 (accessed 28 December 2016).

5 Available at: http://www.alchemywebsite.com/emblems/herm4.gif (accessed 28 December 2016). 
by Merian for Maier's Atalanta Fugiens and for other authors shows this fact, with a notorious relation between the surrealist movement and alchemical imagery. Artists like Ernst, Miró, Carrington or Varo were inspired by its cultural horizon.

One of the artists that were brilliant at recovering the symbolic world of alchemy was the surrealist Leonora Carrington: "Carrington was fully versed in a number of esoteric traditions and her work fluidly employed a vast repertoire of subjects and symbols" [1, p. 97]. The artist recognised that she had had visions that influenced her style: "Well, ever since I was an infant, and I think this is common among many, many more people than you'd think, I had very strange experiences with all kinds of ghosts and visions and things that are generally condemned by orthodox religion" [1, p. 66]. The Lovers $(1987)^{6}$ is one of Carrington's paintings that shows this alchemical background, with the iconographical motif of the Sacred Marriage. That is quite strange in the artist, because she rarely used traditional alchemical symbols like in that painting; she preferred to propose her own symbols frequently based on her life history [15, p. 95].

As a conclusion, the alchemical engravings are the area of art history worth being analysed more deeply and getting a better understanding of. That background translates very complex ideas, related to metaphysical or divine questions, into a symbolic code and in a visual shape. For this reason, it deserves more attention from the scholars, especially art historians as well as science historians. In this paper, we have studied this subject in one instance: the union between the spiritual and the physical that characterizes alchemy in two of their main iconographical motifs: the hermaphrodite and the sacred marriage.

\section{References}

1. Aberth S.L. Leonora Carrington. Surrealism, Alchemy and Art. Aldershot, Hampshire, Lund Humphries Publ., 2004. 160 p.

2. Camillo G. La idea del teatro. Madrid, Siruela Publ., 2006. 240 p. (in Spanish).

3. Choucha N. Surrealism \& the Occult. Oxford, Mandrake Publ., 2015. 164 p.

4. Clulee N.H. Astronomia inferior: Legacies of Johannes Trithemius and John Dee. Secrets of Nature. Astrology and Alchemy in Early Modern Europe. W. R. Newman; A. Grafton (eds.). Cambridge, The MIT Press, 2001, pp. 173-234.

5. Dixon L.S. Bosch's Garden of Delights Triptych: Remnants of a "Fossil" Science. The Art Bulletin, 1981, vol. 63, no. 1, pp. 96-113.

6. Eliade M. Mefistófeles y el andrógino. Barcelona, Labor Publ., 1984, 275 p. (in Spanish).

7. Faivre A. Fuentes antiguas y medievales de los movimientos esotéricos modernos. A. Faivre; J. Needleman (comp.). Espiritualidad de los movimientos esotéricos modernos. Barcelona, Paidós Publ., 2000, pp.37116 (in Spanish).

8. Hanegraaff W. J. From Imagination to Reality: An Introduction to Esotericism and the Occult. Hilma Af Klint: The Art of Seeing the Invisible. K. Almquist; L. Belfrage (eds.). Stockholm, Axel and Margaret Ax:son Johnson Foundation Publ., 2015, pp. 59-71.

9. Lennep J. V. Arte y alquimia. Estudio de la iconografía hermética y de sus influencias. Madrid, Nacional Publ., 1978. 270 p. (in Spanish).

10. Lepetit P. The Esoteric Secrets of Surrealism. Origins, Magic and Secret Societies. Rochester; Toronto, Inner Traditions Publ., 2014. 512 p.

11. Meakin D. Hermetic Fictions. Alchemy and Irony in the Modern Novel. Bodmin, Keele University Press, 1995. $221 \mathrm{p}$.

12. Newman W. R.; Principe L. M. Alchemy Tried in the Fire. Starkey, Boyle, and the Fate of Helmontian Chymistry. Chicago, Chicago University Press Publ., 2002. 344 p.

6 Available at: https://www.wikiart.org/en/leonora-carrington/the-lovers-1987 (accessed 30 December 2016). 
13. Principe L. M.; Newman W. R. Some Problems with the Historiography of Alchemy. Secrets of Nature. Astrology and Alchemy in Early Modern Europe. W. R. Newman; A. Grafton (eds.). Cambridge, The MIT Press, 2001, pp. 385-432.

14. Pseudo Dionisio Areopagita. Obras completas del Pseudo Dionisio Areopagita. Madrid, Biblioteca de autores cristianos Publ., 1990. 418 p. (in Spanish).

15. Szulakowska U. Alchemy in Contemporary Art. Surrey, Ashgate Publ., 2011. 224 p.

16. Warlick M.E. Max Ernst and Alchemy. A Magician in Search of Myth. Austin, University of Texas Press Publ., 2001.309 p.

Title. The Encryption Code: The Symbolic Language of Alchemy Engraving Books.

Author. Roger Ferrer Ventosa - Ph. D. student. University of Girona, Plaça de Sant Domènec, 3, 17004 Girona.Spain.roger.ferrer@udg.edu

Abstract. The aim of the article is to show the artistic value of the alchemical engraving books of the $16^{\text {th }}$ $18^{\text {th }}$ centuries. These books provide art historians with a sophisticated visual symbolic language. The common understanding about alchemy is made of biases and wrong conceptions, even in scientific and historical milieu. In fact, these preconceptions began precisely in this milieu, especially from Enlightenment intellectuals, even though some of the most remarkable scientists in those years studied both chemistry and alchemy, chymistry, such as George Starkey, Robert Boyle or even Isaac Newton.

Symbolical books of this kind are especially interesting for their use of a codified visual language, a way of sharing knowledge by visual skills. Those artists communicated ideas that would not be understood by someone who was not an expert in the subject. Moreover, with this ciphered symbolic language, they provided themselves with protection in times of persecutions.

Moreover, alchemy's cultural horizon is one of the few cases of non-dualism in the Western way of thinking. That is one of the main ideas showed in these engraving books. In alchemy we find several iconographic motifs representing non-dual theories in a visual way. One of them is the representation of a human being with two sexes, an androgyne or a hermaphrodite. A second iconographic motif about non-dualism in that background is the Sacred Wedding: a couple embraced and making love, named hieros gamos by ancient Greeks.

The alchemical framework had a strong influence on some artists of later periods such as William Blake, Max Ernst, or Leonora Carrington and deserves that art historians put more attention to its symbolic language.

Keywords: alchemy; emblems; illuminated manuscripts; engraving books; symbolic language; non-dualism; iconographic motif.

Название статьи. Код шифрования: Символический язык гравюр из книг по алхимии.

Сведения об авторе. Феррер Вентоса, Рожер - аспирант. Университет Жироны, Пласа де Сант Доменек, 3, 17004 Жирона. Испания. roger.ferrer@udg.edu

Аннотация. Целью статьи является утверждение художественной ценности гравюр из книг по алхимии XVI-XVIII вв. Этот тип изданий отличает изощренный символический изобразительный язык. Представления об алхимии, даже в научных кругах, изобилуют неточностями и предрассудками. Вернее, именно в научных кругах и сложились эти предубеждения, восходящие к эпохе Просвещения, несмотря на то, что наиболее выдающие ученые этого периода, Джордж Старки, Роберт Бойль и Исаак Ньютон, изучали и химию, и алхимию, chymistry.

Этот род символической литературы особенно интересен ввиду использования в нем кодифицированного изобразительного языка - визуального способа распространения знаний. Излагая идеи таким образом, мастера гарантировали их защищенность от профанов. Тем более, подобная шифровка обеспечивала им защиту в периоды гонений.

Кроме того, алхимия дает немногие в западном типе мышления примеры идеи недвойственности. Для подобных книг гравюр эта идея является едва ли не центральной. Однако и в алхимии можно обнаружить несколько иконографических мотивов, зримо выражающих эту идею. Один из них - изображение двуполого человеческого существа, андрогина или гермафродита. Другой пример иконографического мотива, воплощающего идею недвойственности, - мистическая свадьба: пара в коронах представлена в момент соития. Древние греки называли это иерогамией.

Гравюры на темы алхимии оказали сильное влияние на некоторых художников более позднего времени, таких как Уильям Блейк, Макс Эрнст или Леонора Каррингтон, и заслуживают того, чтобы историки искусства уделяли больше внимания их символическому языку.

Ключевые слова: алхимия; эмблемы; иллюминированные манускрипты; альбомы гравюр; символический язык; не-дуализм; иконографический мотив, недвойственность; иконографический мотив. 


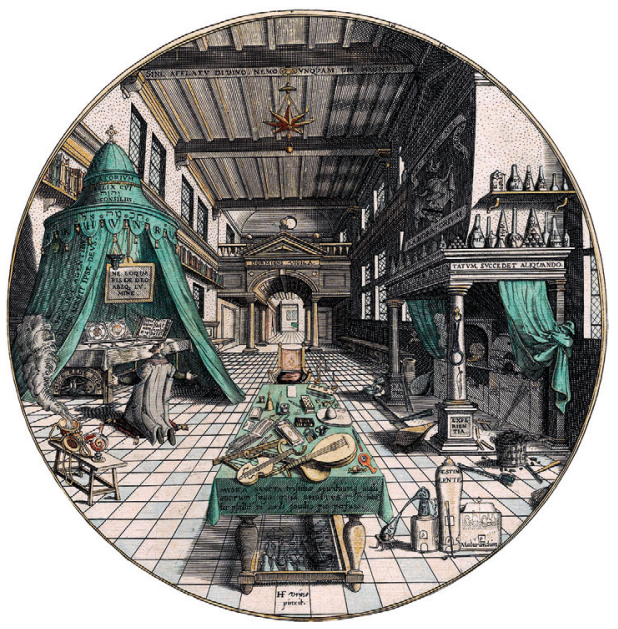

Ill. 24. Vredeman de Vries, in H. Khunrath, "Oratory", Amphitheatrum sapientiae aeternae, 1595. Library of the University of Wisconsin-Madison

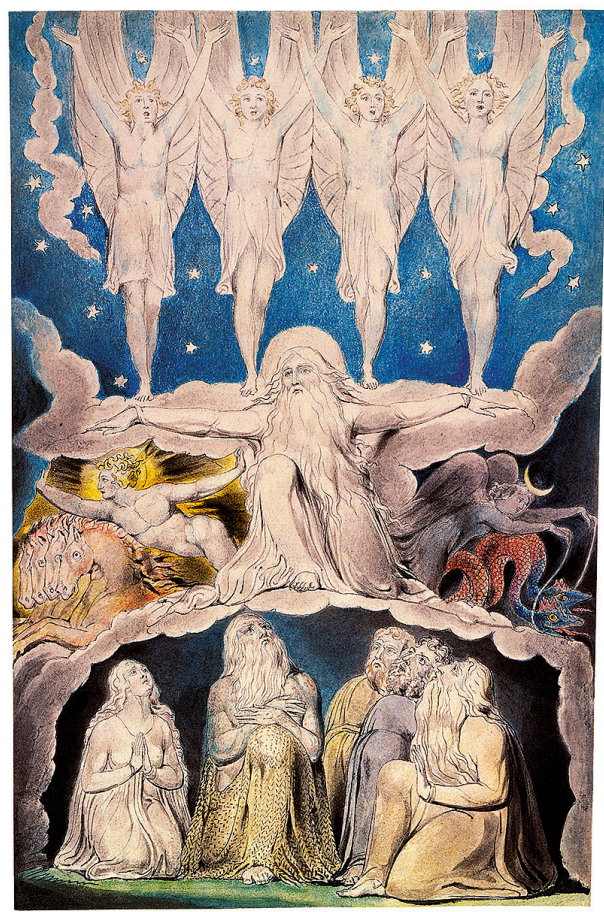

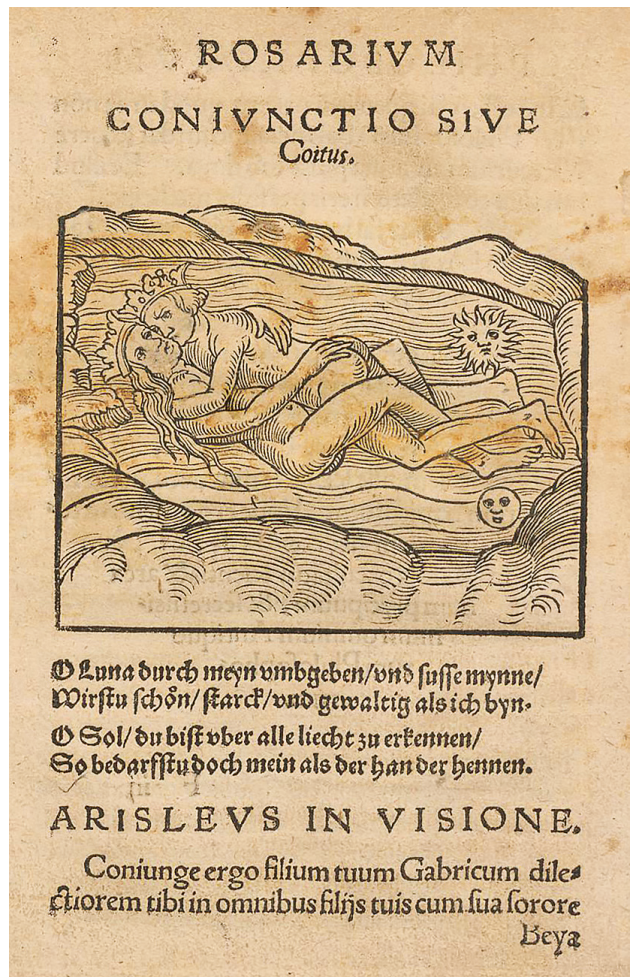

Ill. 26. Anonymous. Rosarium Philosophorum, 1550. Foundation of the Works of C. G. Jung, Zürich, http://dx.doi.org/10.3931/e-rara-10570
Ill. 25. William Blake. "When the Morning Stars Sang Together", The Book of Job, 1805-1810. The Morgan Library, New York 